\title{
"Classification and prioritization of stakeholders' information requests according to Sustainable Development Goals: case of cross-sector partnership in Ukrainian food production industry"
}

\begin{tabular}{|c|c|}
\hline \multirow{5}{*}{ AUTHORS } & Victor Sukhonos (D https://orcid.org/0000-0001-5520-0227 \\
\hline & Inna Makarenko (D https://orcid.org/0000-0001-7326-5374 \\
\hline & $\mathbb{R}$ http://www.researcherid.com/rid/AAE-8453-2020 \\
\hline & Yulia Serpeninova (D) https://orcid.org/0000-0002-4448-3484 \\
\hline & Gunay Qasimova \\
\hline \multirow{4}{*}{ ARTICLE INFO } & $\begin{array}{l}\text { Victor Sukhonos, Inna Makarenko, Yulia Serpeninova and Gunay Qasimova } \\
\text { (2018). Classification and prioritization of stakeholders' information requests }\end{array}$ \\
\hline & according to Sustainable Development Goals: case of cross-sector partnership in \\
\hline & Ukrainian food production industry. Problems and Perspectives in Management, \\
\hline & 16(4), 126-140. doi:10.21511/ppm.16(4).2018.12 \\
\hline DOI & http://dx.doi.org/10.21511/ppm.16(4).2018.12 \\
\hline RELEASED ON & Wednesday, 31 October 2018 \\
\hline RECEIVED ON & Thursday, 26 July 2018 \\
\hline \multirow[t]{2}{*}{ ACCEPTED ON } & Thursday, 20 September 2018 \\
\hline & $(c c)$ EY-NC \\
\hline LICENSE & $\begin{array}{l}\text { This work is licensed under a Creative Commons Attribution-NonCommercial } 4.0 \\
\text { International License }\end{array}$ \\
\hline JOURNAL & "Problems and Perspectives in Management" \\
\hline ISSN PRINT & $1727-7051$ \\
\hline ISSN ONLINE & $1810-5467$ \\
\hline PUBLISHER & LLC “Consulting Publishing Company "Business Perspectives" \\
\hline FOUNDER & LLC "Consulting Publishing Company "Business Perspectives" \\
\hline
\end{tabular}

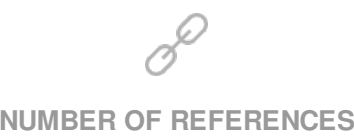

37

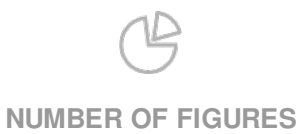

2
NUMBER OF TABLES

6

(C) The author(s) 2023. This publication is an open access article. 


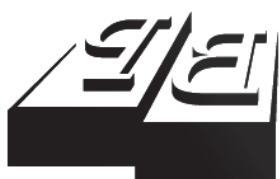

BUSINESS PERSPECTIVES

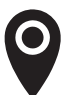

LLC "CPC "Business Perspectives" Hryhorii Skovoroda lane, 10, Sumy, 40022, Ukraine

www.businessperspectives.org

Received on: $26^{\text {th }}$ of July, 2018 Accepted on: $20^{\text {th }}$ of September, 2018

(C) Victor Sukhonos,

Inna Makarenko, Yulia Serpeninova, Gunay Qasimova, 2018

Victor Sukhonos, Professor, Sumy State University, Ukraine.

Inna Makarenko, Associate Professor, Sumy State University, Ukraine.

Yulia Serpeninova, Associate Professor, Sumy State University, Ukraine.

Gunay Qasimova, Lecturer, Khazar University, Azerbaijan.

\section{(ㄷ)(1) $(8)$}

This is an Open Access article, distributed under the terms of the Creative Commons Attribution-NonCommercial 4.0 International license, which permits re-use, distribution, and reproduction, provided the materials aren't used for commercial purposes and the original work is properly cited.
Victor Sukhonos (Ukraine), Inna Makarenko (Ukraine),

Yulia Serpeninova (Ukraine), Gunay Qasimova (Azerbaijan)

CLASSIFICATION

AND PRIORITIZATION

OF STAKEHOLDERS' INFORMATION

REQUESTS ACCORDING TO

SUSTAINABLE DEVELOPMENT

GOALS: CASE OF CROSS-SECTOR

PARTNERSHIP IN UKRAINIAN

FOOD PRODUCTION INDUSTRY

\begin{abstract}
Tracking progress in Sustainable Development Goals (especially Goal 2, Goal 17) substantiates the classification of stakeholders information requests in different sectors of the economy, as well as development of algorithms for selecting the most priority and relevant requests in the context of stakeholder cross-sector partnership. Capital concept and multi-stakeholder approach were recognized as the most appropriate for solving these tasks. This research of existing categories and groups of stakeholders in the real (food production) sector describes the proposed methodology for classifying their information requests and algorithm for their prioritization in relation to a certain type of capital, sustainability dimensions and material topics for stakeholders, SDG, targets, Global Reporting Initiative indicators. The developed methodology is universal both from the point of view of the investigated sectors, the number of alternative stakeholders requests, and the number of experts, as well as from the considerable world experience in prioritizing these requests.
\end{abstract}

\section{Keywords}

JEL Classification

stakeholder, information requests, cross-sector partnership, multi-stakeholder approach, sustainability

\section{INTRODUCTION}

Relying on the European Union Association Agreement, the Sustainability Strategy "Europe 2020" and "Ukraine 2020", and the overall course on sustainable development, the formation of Corporate Social and Environmental Responsibility (CSER) mechanisms in various sectors of the national economy is extremely relevant. Such a task is strategically important both for the companies themselves and for all stakeholders and society as a whole. The solution for the problem is also actualized in view of the low level of perception liability of the real, public and financial sector in civil society and the necessity to ensure the competitiveness of the country as a whole.

The Sustainable Development Goals (SDG) (2017) and their targets should be the start point for companies in different sectors of economy to systematize their activities and analyze their results for ensuring social and environmental responsibility according to key stakeholders' interests and different type of multi-stakeholder partnership. 
Theoretical ground of these partnerships are classical studies of stakeholder theory (Freeman, 1984; Friedman \& Miles, 2002; Garvare \& Johansson, 2010; Post \& Preston, 2002) and multi-stakeholder approach (Hemmati et al., 2002; Gleckman, 2016).

The abovementioned theory and approach concerning SDG achievement had a further development in program documents and guidance by Global Reporting Initiative (2013a, 2013b), International Integrated Reporting Council (2012) and the studies of Masud et al. (2018), Tarquinio et al. (2018), Kuribayashi et al. (2018), Ali et al. (2018), Sen and Ongsakul (2018).

Regional and country-specific features of SDG and sustainable development achievement, classification and prioritization of stakeholders' information requests for the purpose of cross-sector partnership in food and production agricultural industry were investigated in the works of Karwat-Woźniak (2009), Czyżewski and Smędzik-Ambroży (2015), Monaco et al. (2017), Rockström (2017), Govindan (2018), Gonzalez (2017), Anzilago (2018). But these studies do not reflect the Ukrainian evidence in SDG achievements, cross-sector partnership in Ukrainian food production industry and peculiarities of its stakeholders' information requests.

The low level of promotion of CSER's initiatives and the disclosure of information about it by Ukrainian enterprises does not allow to fully monetize the social, economic and environmental impacts of their implementation for stakeholders. The main problem is the lack of understanding of CSER as a means for companies for responding to information requests of stakeholders in different sectors of economy, as well as in food production industry, in the conditions of their cross-sector interaction. These inquiries embody the expectations of stakeholders as regards responsible business conduct of companies, their legitimacy, recognition by civil society, and granting the mandate for achieving SDG.

Therefore, it is extremely important to form the information and analytical support for the national strategy for CSER, which is based on the mechanisms of cross-sector partnership and harmonization of stakeholder's information requests in various sectors and industries of the economy.

The mentioned determines the purpose of study, which is to classify and prioritize the information requests of stakeholders under sustainability and SDG achievement. This purpose should be divided into the following tasks: 1) to form a system of information requests of stakeholders of most relevant industry, as well as their classification for sustainable cross-sector partnership; 2) to develop algorithms for selecting the most priority and relevant stakeholders' information requests of the companies.

Achieving these tasks in the research was conducted according to stakeholder information requests specific in real sector of economy and one of its industries - food production - as a basic industry for ensuring product safety and national progress on SDG 2 (SDG, 2017).

Integral information and analytical support for the mechanism of sustainable cross-sector partnership will lead not only to the progress in achieving the SDG, but will also have a positive impact on the formation of civil society, increase the competitiveness of companies and the state through social, economic and environmental effects.

The remainder of the paper is structured as follows: section 1 provides literature program document review of stakeholders and their information requests types, section 2 provides practical insights in classifying these different requests according to SDG and the most material sustainability issues for the companies in real sector of the economy, section 3 describes the algorithm of stakeholder requests prioritizing for the company - leader in food production in Ukraine, last section concludes with a discussion of the issues raised. 


\section{LITERATURE REVIEW}

During the development of the theoretical and methodological basis of companies' CSER in various sectors of the economy, it is necessary to emphasize the importance of the multi-stakeholder approach in its development. Targets 17.16 and 17.17 of SDG 17 "Strengthen the means of implementation and revitalize the global partnership for sustainable development" testify in favor of its significance. On the one hand, target 17.16 is aimed at strengthening the Global Partnership for Sustainable Development, complemented by multi-stakeholder partnerships that mobilize and share knowledge, experience, technology and financial resources, to support the achievement of the SDG in all countries, in particular, developing countries. Target 17.17 stimulates and facilitates effective public, public-private, and civic partnerships, relying on experience and resource partnership strategies, data, monitoring and accountability (SDG in Ukraine, 2017). On the other hand, taking into account the SDG in the activities of companies will allow them to improve the efficiency of communication with stakeholders on the basis of sustainability reporting and progress towards the Goals.

The theoretical basis of cross-sector partnership is the multi-stakeholder approach. It describes a process, which is aimed at uniting the main stakeholders in new forms of communication, search and decision making, and structure on specific issues; this is based on the recognition of the importance of capital reproduction and the achievement of accountability in communications with stakeholders; this approach attracts a presentation of the main groups of stakeholders and their positions; this is based on democratic principles of transparency and participation and aimed at building partnerships and networks among stakeholders (Hemmati et al., 2002). This approach finds further development in multi-stakeholder governance concept "multi-stakeholderism" as Global Reporting Initiative and World Economic Forum joint projects (Gleckman, 2016).

Taking into account the influence of the environment and disclosing of the information about the companies' ability to respond to these impacts is related to the understanding of the sustainability reporting process with identifying stakeholders as key person or organization, which represents its internal and external environment, proposed by Freeman - founder of the theory of stakeholders (Freeman, 1984). Post and Preston (2002) recognize the relationships between corporation and stakeholders as "asset relationships" that consent it to generate goods over a long period of time, and it is an instrument for achieving sustainability, which is consistent with the understanding of social and communication capital, and corresponds to practice of structuring the capital under capital concept of the International Integrated Reporting Council (International Integrated Reporting Council, 2012).

Within the framework of communication theory, communication with stakeholders is carried out by means of sustainability reporting, accounting acts as a system of signal formation in the context of indicators of sustainable development, stakeholders' information needs and requests. Just the satisfaction of the information needs of stakeholders (information openness and transparency of the company's activities) is the main reason for the preparation of sustainability reporting with different capital types for companies' stakeholders in the financial and real sectors (Ernst \& Young, GreenBiz Group, 2013).

The importance of relationships with stakeholders is also highlighted by other well-known organizations. According to the research of KPMG, about $40 \%$ of CSER reports have a separate section on company stakeholders (KPMG, 2011).

According to the Global Reporting Initiative standard and guidelines, the state of these relationships with stakeholders must necessarily be disclosed in the company's non-financial report. Another standard, the AA1000, advises to prepare a non-financial report based on a dialogue with stakeholders. AE 1000 SES standard (Stakeholder Engagement Standard) regulates the activities of organizations in planning, executing, evaluating, informing and non-financial audits checkup of quality of interaction with stakeholders (Account Ability, 2015). 
In general, the stakeholders in the standard of corporate social responsibility, ISO 26000, are understood as a person or group of individuals interested in any decision or activity of the organization (ISO 26000). According to the AA1000SES standard, stakeholders are those groups that have an influence on activities, products, or services or may be under their influence (AccountAbility, 2015). The Global Reporting Initiative also provides a similar definition: stakeholders are the organizations or individuals which, according to reasonable expectations, are substantially affected by the activities, products and/or services of the organization, and those whose actions, according to reasonable expectations, may affect the ability of an organization to successfully implement its strategies and to achieve the set goals (Global Reporting Initiative, 2013).

Summarizing different approaches allows, among the number of stakeholders, to highlight the following key groups: employees, investors, customers, suppliers, competitors, government and regulatory authorities, business partners, local communities, scientific community, media, non-governmental organizations and lobby. According to the SDG, among the key users of information, capital providers, general public, government agencies and other key stakeholders were highlighted (UNCTAD, 2016).

Some piece of academic studies investigates the types and roles of stakeholders for companies of different sectors (Wheeler \& Sillanpa, 1997; Friedman \& Miles, 2002; Podnar \& Jancic, 2009; Garvare \& Johansson, 2010).

Taking into account these studies and research conducted by the Global Reporting Initiative on the most significant topics of sustainability reporting relative to stakeholders information requests (Global Reporting Initiative (2013a, 2013b), International Integrated Reporting Council (2012), we propose to identify key stakeholder groups as owners (providers) of certain types of capital for the company. Process of stakeholders' identification plays a crucial role to further mapping of their information requests and building of indicators system for disclosure of sustainability information by the company.
Among the key stakeholder groups within each of the investigated sectors, we differentiate the organizations involved in providing loan (financial) capital, creating the manufacturing capital, forming a network of social communications (social capital), reproducing the natural resources (natural capital) with established information requests (Table 1) and whose information needs are transformed under sustainability.

Table 1. Key stakeholder groups in accordance with the concept of capital and multi-stakeholder approach

Source: Authors' development on the basis of International Integrated Reporting Council (2012).

\begin{tabular}{|c|c|c|c|}
\hline Capital & $\begin{array}{c}\text { Group (capital } \\
\text { providers) }\end{array}$ & $\begin{array}{c}\text { Motives for } \\
\text { engagement } \\
\text { and stakeholder } \\
\text { information } \\
\text { requests }\end{array}$ & 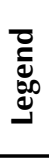 \\
\hline Financial & $\begin{array}{l}\text { Investors, lenders, } \\
\text { shareholders }\end{array}$ & $\begin{array}{l}\text { Effective usage } \\
\text { and increasing } \\
\text { of financial } \\
\text { resources }\end{array}$ & $\mathrm{F}$ \\
\hline Manufacturing & $\begin{array}{l}\text { Contractors } \\
\text { (suppliers, } \\
\text { contractors), } \\
\text { business } \\
\text { and trade } \\
\text { associations } \\
\text { (business } \\
\text { partners) }\end{array}$ & $\begin{array}{l}\text { Ability to fulfill } \\
\text { the obligations } \\
\text { undertaken by } \\
\text { the company, } \\
\text { the formation } \\
\text { of stable supply } \\
\text { chains }\end{array}$ & M \\
\hline Human & $\begin{array}{l}\text { Board of } \\
\text { directors, } \\
\text { managers, } \\
\text { employees, } \\
\text { trade unions, } \\
\text { organizations for } \\
\text { the protection of } \\
\text { human rights }\end{array}$ & $\begin{array}{l}\text { Motivation for } \\
\text { work, material } \\
\text { remuneration and } \\
\text { social security }\end{array}$ & $\mathrm{H}$ \\
\hline Social & $\begin{array}{l}\text { Local } \\
\text { communities, } \\
\text { civic } \\
\text { organizations, } \\
\text { media, academic } \\
\text { and educational } \\
\text { institutions, } \\
\text { intermediary } \\
\text { institutions } \\
\text { (rating agencies, } \\
\text { experts), impact } \\
\text { groups, lobby, } \\
\text { charitable } \\
\text { organizations, } \\
\text { government } \\
\text { institutions }\end{array}$ & $\begin{array}{l}\text { Recognition } \\
\text { of company } \\
\text { legitimacy, } \\
\text { granting of } \\
\text { "license" for } \\
\text { activity, formation } \\
\text { of trust and } \\
\text { partnership } \\
\text { relations }\end{array}$ & S \\
\hline $\begin{array}{l}\text { Intellectual } \\
\text { (intangible) }\end{array}$ & $\begin{array}{l}\text { Consumers, } \\
\text { clients, } \\
\text { associations of } \\
\text { consumer's rights } \\
\text { protection }\end{array}$ & $\begin{array}{l}\text { Loyalty to the } \\
\text { brand, orientation } \\
\text { towards } \\
\text { reputation }\end{array}$ & I \\
\hline Natural & $\begin{array}{l}\text { State regulatory } \\
\text { institutions, } \\
\text { government } \\
\text { agencies, } \\
\text { environmental } \\
\text { organizations, } \\
\text { organizations for } \\
\text { the protection of } \\
\text { animal rights }\end{array}$ & $\begin{array}{l}\text { Preservation and } \\
\text { rational usage of } \\
\text { natural resources } \\
\text { and rent payment }\end{array}$ & $\mathrm{N}$ \\
\hline
\end{tabular}


In our opinion, incorporation of multi-stakeholder approach and capital concept into companies CSER activity and sustainability strategy for achieving SDG gives the company a number of additional benefits:

- comprehensive information disclosure for stakeholders, synergistic combination of different kinds of companies resources (labor, intellectual, financial) aimed at achieving the SDG;

- increasing the transparency of the company's activities and improving its reputation, processes for decision making, managing sustainability risks in accordance with stakeholders' information requests.

Thus, during the research of existing categories and groups of stakeholders of the real, public and financial sectors, the feasibility and peculiarities of the application of the multi-stakeholder approach and mechanism of their cross-sectoral partnership were determined, the necessity for classification and prioritization of stakeholders' information requests, the investigated sectors for their relation to a certain type of capital were established.

\section{CLASSIFICATION OF STAKEHOLDERS' INFORMATION REQUESTS IN THE REAL SECTOR OF ECONOMY}

An integral part of the information and analytical support for sustainable development, along with the stakeholder's information requests identification, is their classification and prioritization. The applied aspect of classification and prioritization of information requests of stakeholders was based on the companies in the real sector, namely, food production.

The food production sector is one of the largest sectors of the global economy, and its influence on the formation of sustainable business practices and ecosystem conservation is leading. Meeting the needs of consumers, forming a positive image on the markets for agricultural products, entering new commodity markets for environmental products, and establishing effective communications with stakeholders call on companies in this area to take into consideration the challenges of sustainable development.

Among the SDG 17, Goal 2 is related to overcoming hunger, achieving food security, improving nutrition, and promoting sustainable agricultural development, and becomes of particular importance in modern conditions (SDG, 2017). Considering the multiplicity of objectives of Goal 2, a significant list of industries and spheres of the food sector, the specifics of its functioning in each country, the information requests of stakeholders can vary considerably. Their classification, in order to meet them and to disclose the necessary information in food sector companies' sustainability reporting in Ukraine, requires additional analysis.

Foreign organizations of different levels have their own approaches to determining the most important information requests of stakeholders in this sector. Thus, the Governance \& Accountability Institute, according to the comparative analysis of sustainability reporting, published by 26 companies - world leaders in this sector - develops the most relevant sustainability topics for stakeholders. They are the usage of child labor; prevention of forced labor placement in the food sector; conservation, protection and promotion of biodiversity reproduction; state policy coordination with SDG; conservation and rational usage of water resources (Global Reporting Initiative, 2014).

The Global Reporting Initiative proposes to analyze the compliance of the companies in the food sector with 69 common subjects 13: specific subjects for companies - producers of plant agricultural products and 26 specific subjects for companies - producers of livestock farming. All subjects are structured according to the key dimensions of sustainable development - environmental, economic and social, and cover more than 80 specific areas. Among the key stakeholder groups, there are organizations associated with the commercial sector, including business and trade associations; intermediary institutions or experts such as consultants, academic institutions, governments and intergovernmental institutions and analyti- 
Source: Developed by authors on the basis of SDD Database (2018).

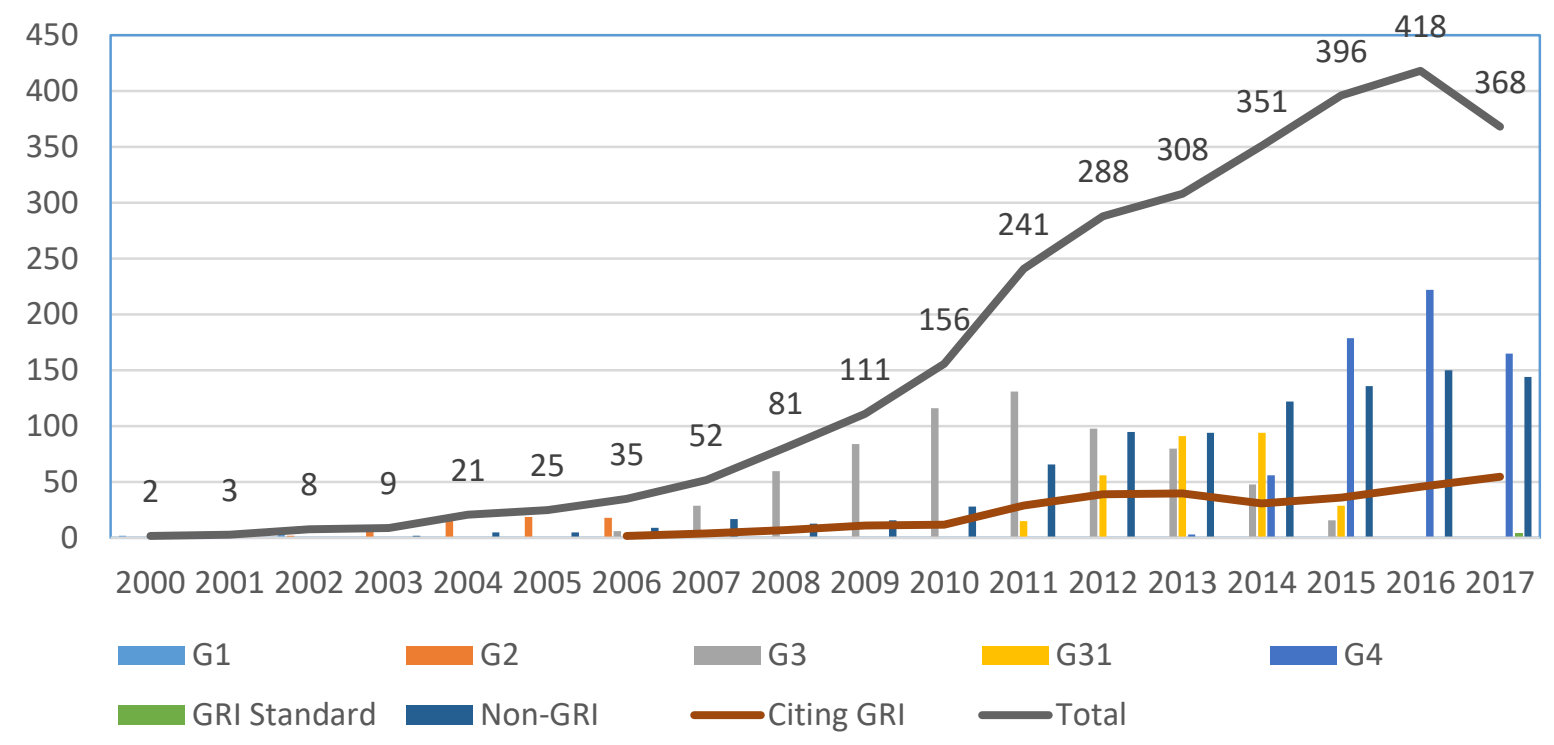

Figure 1. GRI reporting of food and beverage products on CSER mechanism and SDG's progress in world in the period 2000-2017, reports

cal centers; civil society organizations, including non-governmental organizations, trade unions, experts and end-users of information (Global Reporting Initiative, 2013b).

Sustainability Disclosure Database, powered by Global Reporting Initiative (SDD Database, 2018), shows constant growth (Figure 1) in world largest food production companies reports, no matter the type of reporting standards chosen by GRI (G1, G2, G3, G3.1, G4, citing GRI, GRI Standards or non-GRI).

These reports disclose companies CSER activities and SDG's progress (from 2015). Among the key areas for the sustainability information disclosure for food companies' stakeholders, Sustainability Assessment of Food and Agriculture systems guidelines (SAFA, 2013) perceive: good governance, environmental integrity, economic sustainability and social well-being, which in its turn are divided into 21 main subjects and 58 subjects. It allows to create a transparent and comprehensive framework for highlighting key stakeholders sustainability requests in this sector of the economy.

Thus, individual organizations such as the Institute for Governance \& Accountability, the Global Reporting Initiative, the United Nations Food and Agriculture Organization have devel- oped baselines of the minimum required information to be disclosed by companies operating in the agrarian sector to meet the needs of stakeholders and can be used as a benchmark.

We propose to classify the stakeholders information requests of this sector of the economy in accordance with their materiality for individual groups of stakeholders in accordance with the proposed basis for their identification (capital concept and multi-stakeholder approach), sustainability dimensions (ecological (Ecol.), social (S) and economical (E)) and SDG, their target, specified in certain sustainability reporting indicators.

The selection of indicators, which specify the information requests of stakeholders in accordance with the most significant sustainability topics, should meet such criteria:

- multipurpose, integral and interrelated nature and coverage of three dimensions of sustainable development;

- voluntary nature;

- long-term orientation;

- openness, inclusiveness, transparency and opportunity for all; 
- human-centricity and gender sensitivity, concentration on human rights and vulnerable population groups (UNCTAD, 2016).

We suggest to include to the list of indicators on SDG progress indicators developed by the Global Reporting Initiative (defined by the new GRI Standards and the previous G4 guidance, where it is appropriate). The proposed scheme of classification of the relevant information requests of stakeholders in the food production sector was presented in Table 2. According to the approaches of the Global Reporting Initiative, producers of agro-in- dustrial products, including those involved in the cultivation of grain, owners of agricultural land, companies engaged in raising livestock and production of meat, poultry, fish, milk, as a whole companies that are engaged in the production of food products, except those engaged in forestry, were included into the list companies of this sector (Global Reporting Initiative, 2013b).

Thus, on the basis of systematization and sustainability disclosure of the stakeholder information requests in food production (real sector), methodological approach to their classification was im-

Table 2. Classification of stakeholders' information requests relevant to SDG, their targets and indicators economy (based on the example of food production sector)

Source: Developed by authors on the basis of Global Reporting Initiative (2013b), Global Reporting Initiative (2018), SDG (2017).

\begin{tabular}{|c|c|c|c|c|c|}
\hline \multirow{2}{*}{$\begin{array}{l}\text { Stake- } \\
\text { holders }\end{array}$} & \multicolumn{2}{|c|}{ Key information requests } & \multirow{2}{*}{$\begin{array}{l}\text { Sustainability } \\
\text { dimension }\end{array}$} & \multirow{2}{*}{$\begin{array}{l}\text { Targets } \\
\text { of SDG }\end{array}$} & \multirow{2}{*}{ GRI indicator } \\
\hline & Subject & Issue & & & \\
\hline$M, F$ & Economic efficiency & $\begin{array}{l}\text { Financial efficiency and } \\
\text { assistance of international } \\
\text { organizations }\end{array}$ & $E$ & 8.1 & $\begin{array}{l}\text { Economic added value GRI } \\
\text { Standard 201-1 }\end{array}$ \\
\hline$S, M, F$ & $\begin{array}{l}\text { Socio-economic } \\
\text { benefits }\end{array}$ & $\begin{array}{l}\text { Production of biomass and } \\
\text { bioenergy }\end{array}$ & $\mathrm{E}$ & 8.2 & $\begin{array}{l}\text { Economic added value GRI } \\
\text { Standard } 201-1\end{array}$ \\
\hline \multirow{5}{*}{$\mathrm{N}, \mathrm{S}$} & \multirow{5}{*}{$\begin{array}{l}\text { Efficiency in the use } \\
\text { of material, land, } \\
\text { water, biological, } \\
\text { energy resources, air } \\
\text { purity }\end{array}$} & $\begin{array}{l}\text { Reducing of the irrational } \\
\text { energy usage, energy-saving } \\
\text { technologies }\end{array}$ & Ecol., S & 8.4 & $\begin{array}{l}\text { Total energy consumption by } \\
\text { the company, reduction of } \\
\text { consumption, etc. } \\
\text { GRI Standard } 302-1-5\end{array}$ \\
\hline & & $\begin{array}{l}\text { Rational usage of water } \\
\text { resources }\end{array}$ & Ecol., S & 8.4 & $\begin{array}{l}\text { Recycling of water resources } \\
\text { GRI Standard } 303-3\end{array}$ \\
\hline & & $\begin{array}{l}\text { Material efficiency and } \\
\text { production on the basis of } \\
\text { sustainable development }\end{array}$ & Ecol., S & 8.4 & $\begin{array}{l}\text { The share of restorative } \\
\text { materials } \\
\text { GRI Standard } 301-1,2\end{array}$ \\
\hline & & GHG emissions & Ecol., S & 7.3 & $\begin{array}{l}\text { The coefficient of energy } \\
\text { efficiency of the company } \\
\text { GRI Standard } 305-1.2\end{array}$ \\
\hline & & Reclamation of soils & Ecol., S & 15.3 & - \\
\hline $\mathrm{S}, \mathrm{H}, \mathrm{M}$ & Social development & Food and social security & $\mathrm{S}, \mathrm{E}$ & $2.1-2.5$ & - \\
\hline \multirow[t]{2}{*}{$\mathrm{S}, \mathrm{H}, \mathrm{Int}$} & \multirow[t]{2}{*}{$\begin{array}{l}\text { Human capital } \\
\text { development }\end{array}$} & Safe working conditions & $\mathrm{S}$ & 8.8 & $\begin{array}{l}\text { Professional Health and Safety } \\
\text { GRI Standard } 403-1-4 \\
\text { Usage of labor practices in } \\
\text { supply chains } \\
\text { GRI Standard } 414-1.2\end{array}$ \\
\hline & & $\begin{array}{l}\text { Training and staff } \\
\text { development }\end{array}$ & $\mathrm{S}$ & 8.5 & $\begin{array}{l}\text { Trainings and education for } \\
\text { the staff } \\
\text { GRI Standard } 404-1-3\end{array}$ \\
\hline \multirow[b]{2}{*}{$\mathrm{S}, \mathrm{H}, \mathrm{M}$} & \multirow[b]{2}{*}{$\begin{array}{l}\text { Food safety } \\
\text { management systems }\end{array}$} & $\begin{array}{l}\text { Standards of quality and } \\
\text { safety of food products }\end{array}$ & S, E & \multirow[b]{2}{*}{2.5} & - \\
\hline & & $\begin{array}{l}\text { The usage of genetic } \\
\text { engineering and modified } \\
\text { products, nutritional value } \\
\text { and product safety }\end{array}$ & S, E, Ecol. & & - \\
\hline \multirow[t]{2}{*}{$\mathrm{S}, \mathrm{F}, \mathrm{N}$} & \multirow[t]{2}{*}{ Partnership } & \multirow[t]{2}{*}{$\begin{array}{l}\text { Indirect economic impact } \\
\text { on the community and } \\
\text { employment }\end{array}$} & \multirow[t]{2}{*}{$\mathrm{E}$} & \multirow[t]{2}{*}{8.3} & $\begin{array}{l}\text { Examples and implications } \\
\text { of indirect impacts on } \\
\text { the community in the } \\
\text { context of comparison with } \\
\text { benchmarking, stakeholder } \\
\text { priorities and international } \\
\text { protocols } \\
\text { GRI Standard } 203-2\end{array}$ \\
\hline & & & & & $\begin{array}{l}\text { The share of local purchases } \\
\text { in the general budget } \\
\text { GRI Standard 204-1 }\end{array}$ \\
\hline
\end{tabular}


proved. Universal nature of this approach allows to form a holistic system of such requests as the basis of information provision of the cross-sector partnership mechanism of the mentioned stakeholders.

\section{PRIORITIZATION OF STAKEHOLDERS' INFORMATION REQUESTS: CASE STUDY FOR UKRAINIAN FOOD SECTOR AND MHP}

In Ukraine, the stakeholder information requests disclosure in sustainability reporting about SDG's progress in food production sector companies is in its initial stage. CSR Case Contest (2018) results in the period 2016-2017 demonstrate low CSER perception and stakeholders' engagement for SDG's progress for Goal 2 End hunger, achieve food security and improved nutrition and promote sustainable agriculture, as well as Goal 1 End poverty in all its forms everywhere, Goal 6 Ensure availability and sustainable management of water and sanitation for all, Goal 7 Ensure access to affordable, reliable, sustainable and modern energy for all, Goal 10 Reduce inequality within and among countries (Figure 2) in 46 observed companies. The most relevant for the Ukrainian companies with famous CSER practice according to external and internal stakeholder engagement and their information request inclusion are (in descending order) Goal 12 Ensure sustainable consumption and production pattern, Goal 11 Make cities and human settlements inclusive, safe, resilient and sustainable, Goal 10 Reduce inequality within and among countries, Goal 3 Ensure healthy lives and promote well-being for all at all ages, Goal 8 Promote sustained, inclusive and sustainable economic growth, full and productive employment and decent work for all, Goal 13 Take urgent action to combat climate change and its impacts, Goal 4 Ensure inclusive and equitable quality education and promote lifelong learning opportunities for all and Goal 5 Achieve gender equality and empower all women and girls (CSR Case Contest, 2018).

Moreover, only three companies of this sector (Astarta, Kernel, and Myronivsky Hliboproduct (MHP)) have published their CSER and sustainability reports in Global Reporting Initiative within stakeholder requests since 2012.

Among the Astarta priorities in developing communication practices with stakeholders, the company considers involvement in common social projects, communities, business and public organizations, communication with communities and stakeholders, including through non-financial reporting in order to increase the confidence of stakeholders (Astarta, 2016). Besides to Astarta, which regularly publishes its non-financial information from 2012, the Global Reporting Initiative has reports with a certain degree of disclosure of communications with stakeholders of two more Ukrainian agriculture companies - Kernel and

Source: Developed by authors on the basis of CSR Case Contest (2018).

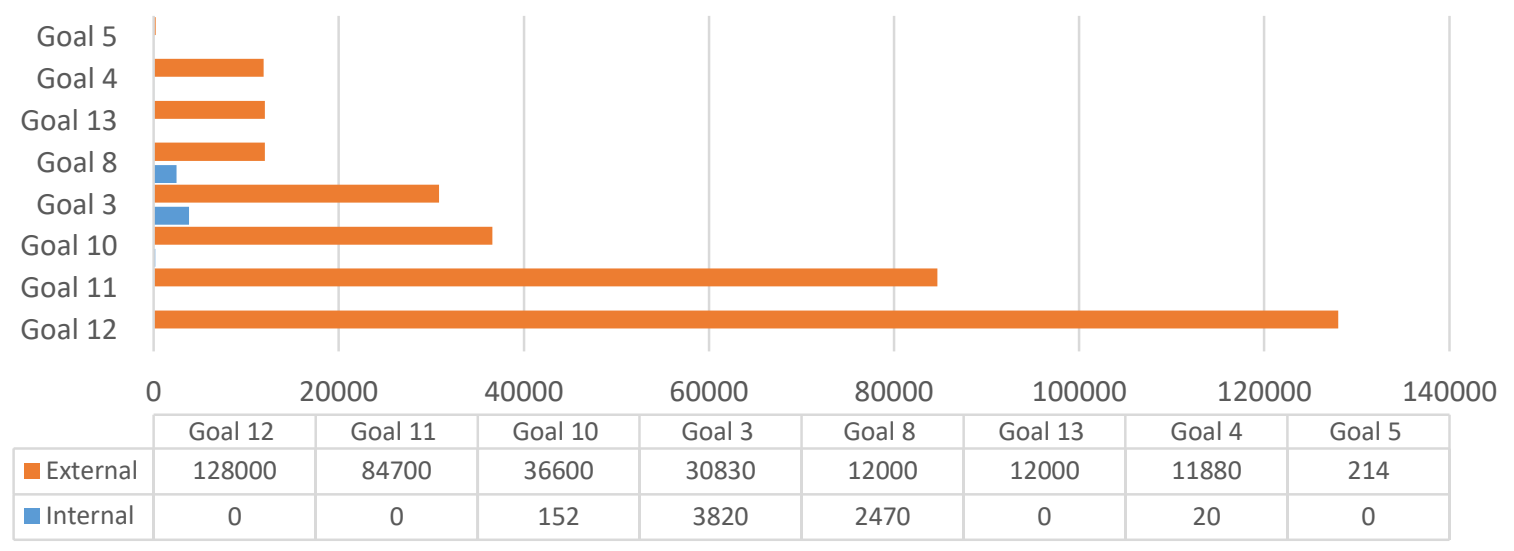

Figure 2. External and internal stakeholders engagement in SDG' progress in the period 2016-2017 in 46 Ukrainian companies, person 
Myronivskyi Khliboprodukt (MHP). This situation signals about the emergence of reporting practices and disclosure of information in accordance with stakeholders' requests for sustainable development in Ukraine. The extension of sustainability reporting publising by companies is a basis for information and analytical support for food sector sustainable development and to achieve progress towards the SDG in other sectors of the economy.

We will consider a system of stakeholders' information requests and their prioritization on an example of MHP. By definition of MHP, a stakeholder is an individual or legal entity/group of persons who are interested in activities and/or engage in cooperation with the MHP Group. Interaction with stakeholders is one of the important activities of the company. This process involves partnership and consultation arrangements and reporting, as well as interaction and communication with groups and individuals interested in the company or its businesses. The main criterion for identifying stakeholders is the geographical location of a particular enterprise, as well as its sphere of activity.

The MHP's relationship with stakeholders, as outlined in the company's non-financial report for 2016 and previous years, is characterized by a rather close level of interaction. During the last year, MHP has been developed and implemented:

- Corporate Social Responsibility Policy of PJSC "Myronivskyi Khliboprodukt";

- plan of interaction with the stakeholders of PJSC "Myronivskyi Khliboprodukt";

- communication policy of PJSC "Myronivskyi Khliboprodukt".

Despite the developed system of corporate policies on sustainability and interaction with stakeholders in the company:

- there is no formalized procedure for prioritization and assessment of the information requests materiality, which negatively affects the coverage of the most important reporting issues for company's stakeholders; the SDG are not taking into consideration in the process of stakeholders' request response;

there is no sustainability context and reporting indicators of the Global Reporting Initiative, although the company declares compliance with the report to the G3 Management;

there are no procedures for selecting information requests and there are no algorithms for their ranking.

To eliminate these disadvantages, we offer:

1) to correct the most important stakeholders' information requests according to the sustainability context, identify the most relevant requests and corresponding indicators in the non-financial report of the MHP and disclosure additional information about these requests along with company's progress in SDG;

2) to develop an algorithm for ranking and prioritization of these information requests with the help of the Board's rule;

3) to form an approach to the interpretation of the results with its subsequent visualization and anchoring to the best practice of determining information requests under sustainability concept and their significance for stakeholders.

The identification of the key groups of the stakeholders of the MHP, the areas of their information requests, specific features of interaction and communication and the main information requests in 2016 are presented in Table 3.

The information requests of MHP's stakeholders were ranked and adapted to the sustainability context, taking into consideration developed classification system in previous section of the work. Among such requests, company should consider the following (Table 4): mass media and media as a categories of stakeholders, characterized by the request "informing about the company's activities", were reckoned with including to other categories due to the traditional type of request. 
Table 3. Categories of stakeholders and their information requests by the MHP company

Source: Supplemented by the authors in accordance with MHP $(2016,2017)$.

\begin{tabular}{|c|c|c|c|c|}
\hline Categories & Stakeholders & $\begin{array}{l}\text { Areas of } \\
\text { information } \\
\text { request }\end{array}$ & $\begin{array}{l}\text { Features of interaction and } \\
\text { communication }\end{array}$ & $\begin{array}{l}\text { Key issues from } \\
\text { stakeholders in } \\
2016\end{array}$ \\
\hline $\begin{array}{l}\text { Authority/ } \\
\text { government } \\
\text { agencies }\end{array}$ & $\begin{array}{l}\text { State authorities } \\
\text { at all levels in } \\
\text { the company's } \\
\text { presence }\end{array}$ & $\begin{array}{l}\text { Socio-economic } \\
\text { cooperation }\end{array}$ & $\begin{array}{l}\text { Mutually beneficial partnership; socio-economic } \\
\text { cooperation; realization of common programs } \\
\text { and projects for raising the standard of living } \\
\text { of the population, solving urgent issues of the } \\
\text { regions; cooperation in the field of business } \\
\text { activities }\end{array}$ & Partnership \\
\hline $\begin{array}{l}\text { Society/local } \\
\text { communities }\end{array}$ & $\begin{array}{l}\text { Residents of } \\
\text { settlements in the } \\
\text { presence of the } \\
\text { company }\end{array}$ & $\begin{array}{l}\text { Coverage of } \\
\text { activities, } \\
\text { interaction with } \\
\text { the population, } \\
\text { mutually beneficial } \\
\text { partnership }\end{array}$ & $\begin{array}{l}\text { Building of trusted and mutually beneficial } \\
\text { partnerships with communities in the regions of } \\
\text { presence; development of projects that will lead } \\
\text { to an increase of the living standards of the local } \\
\text { population; interaction with the public, provides } \\
\text { for the implementation of infrastructure projects, } \\
\text { promotion of social and cultural development, } \\
\text { implementation of energy saving projects } \\
\text { and other measures; accurate and up-to-date } \\
\text { information on plans and activities }\end{array}$ & $\begin{array}{l}\text { Partnership } \\
\text { Influence of the } \\
\text { company on social, } \\
\text { ecological and } \\
\text { cultural spheres }\end{array}$ \\
\hline Employees & $\begin{array}{l}\text { Staff of the } \\
\text { company, trade } \\
\text { unions }\end{array}$ & $\begin{array}{l}\text { Organization } \\
\text { of work of the } \\
\text { enterprise }\end{array}$ & $\begin{array}{l}\text { Creating conditions for an objective assessment } \\
\text { and recognition of the merit of all and each of its } \\
\text { employees; formation of a system of training and } \\
\text { development of mentoring; development of the } \\
\text { payroll system and personnel motivation }\end{array}$ & $\begin{array}{l}\text { Comfortable and } \\
\text { safe working } \\
\text { conditions, } \\
\text { professional } \\
\text { development } \\
\text { influence of the } \\
\text { company on social, } \\
\text { ecological and } \\
\text { cultural spheres }\end{array}$ \\
\hline $\begin{array}{l}\mathrm{NPO} / \\
\text { association of } \\
\text { citizens }\end{array}$ & $\begin{array}{l}\text { Association } \\
\text { of citizens, } \\
\text { organizations, } \\
\text { educational } \\
\text { organizations }\end{array}$ & $\begin{array}{l}\text { Informing about } \\
\text { activities and social } \\
\text { cooperation }\end{array}$ & $\begin{array}{l}\text { Fruitful cooperation to improve the lives of } \\
\text { citizens; development and implementation of } \\
\text { environmental, social and cultural programs; } \\
\text { informing about company activity }\end{array}$ & $\begin{array}{l}\text { Comfortable and } \\
\text { safe working } \\
\text { conditions, } \\
\text { professional } \\
\text { development } \\
\text { partnership; } \\
\text { influence of the } \\
\text { company on social, } \\
\text { ecological and } \\
\text { cultural spheres }\end{array}$ \\
\hline $\begin{array}{l}\text { Media/mass } \\
\text { media }\end{array}$ & $\begin{array}{l}\text { Regional, all- } \\
\text { Ukrainian mass } \\
\text { media }\end{array}$ & $\begin{array}{l}\text { Notification of the } \\
\text { information about } \\
\text { company for all } \\
\text { stakeholders }\end{array}$ & $\begin{array}{l}\text { Distribution of trustworthy and truthful } \\
\text { information about the group's activities; } \\
\text { dissemination of information about plans, } \\
\text { changes, news; prompt provision of comments, } \\
\text { answers to requests }\end{array}$ & All kinds of requests \\
\hline $\begin{array}{l}\text { Commercial } \\
\text { organizations }\end{array}$ & $\begin{array}{l}\text { Business partners, } \\
\text { clients, consumers }\end{array}$ & $\begin{array}{l}\text { Organization and } \\
\text { conducting of } \\
\text { commercial activity } \\
\text { of the company, } \\
\text { mutually beneficial } \\
\text { cooperation }\end{array}$ & $\begin{array}{l}\text { Fair and transparent business relations, honesty } \\
\text { with business partners; compliance with the } \\
\text { assumed obligations; prevention of corruption; } \\
\text { mutually beneficial partnership; improvement } \\
\text { of client service; meeting the needs of different } \\
\text { groups of consumers }\end{array}$ & Partnership \\
\hline $\begin{array}{l}\text { International } \\
\text { organizations }\end{array}$ & $\begin{array}{l}\text { National and } \\
\text { supranational } \\
\text { organizations } \\
\text { (Food and } \\
\text { Agriculture } \\
\text { Organization } \\
\text { of the United } \\
\text { Nations) }\end{array}$ & $\begin{array}{l}\text { Realization of } \\
\text { common programs } \\
\text { and actions for the } \\
\text { purpose of quality } \\
\text { control of products, } \\
\text { improvement of } \\
\text { production }\end{array}$ & $\begin{array}{l}\text { Implementation of programs and actions aimed } \\
\text { at improving the quality of products, production } \\
\text { processes at enterprises, implementation of } \\
\text { socially significant international projects in } \\
\text { Ukraine in order to improve the quality of } \\
\text { life of the population or certain groups of } \\
\text { the population (socially vulnerable, children, } \\
\text { disabled people, etc.) }\end{array}$ & $\begin{array}{l}\text { Comfortable and } \\
\text { safe working } \\
\text { conditions, } \\
\text { professional } \\
\text { development } \\
\text { Product quality, } \\
\text { production control }\end{array}$ \\
\hline Investors & $\begin{array}{l}\text { Banks, eurobond } \\
\text { holders, } \\
\text { shareholders, } \\
\text { international } \\
\text { financial } \\
\text { institutions }\end{array}$ & $\begin{array}{l}\text { Financial and } \\
\text { operational } \\
\text { activities, informing } \\
\text { about key events }\end{array}$ & $\begin{array}{l}\text { Maintenance of regular contacts with investors; } \\
\text { Providing investors with relevant and complete } \\
\text { information about promotions, financial reports, } \\
\text { financial calendars, analytics, etc. }\end{array}$ & $\begin{array}{l}\text { Comfortable and } \\
\text { safe working } \\
\text { conditions, } \\
\text { professional } \\
\text { development } \\
\text { Financial and } \\
\text { operational } \\
\text { activities, corporate } \\
\text { governance }\end{array}$ \\
\hline
\end{tabular}


Table 4. Information requests of MHP stakeholders, adjusted for the sustainability context

Source: Developed by authors on the basis of own approach and Global Reporting Initiative (2018).

\begin{tabular}{|c|c|c|c|c|}
\hline Request & Category of stakeholders & $\begin{array}{l}\text { Classification } \\
\text { on the basis } \\
\text { of capital }\end{array}$ & SDG & GRI indicator \\
\hline $\begin{array}{l}\text { Human capital development } \\
\left(x_{1}\right)\end{array}$ & $\begin{array}{l}\text { Employees, trade unions, international and } \\
\text { educational organizations, mass media }\end{array}$ & $\mathrm{S}, \mathrm{H}, \mathrm{I}$ & $8.5,8.8$ & $\begin{array}{c}\text { GRI Standard 403- } \\
1-4,414-1,2\end{array}$ \\
\hline $\begin{array}{l}\text { Economic efficiency and } \\
\text { socio-economic benefits }\left(x_{2}\right)\end{array}$ & $\begin{array}{l}\text { Investors, international organizations, mass } \\
\text { media }\end{array}$ & $\mathrm{S}, \mathrm{N}, \mathrm{F}$ & 8.1-8.3 & $\begin{array}{l}\text { GRI Standard 201- } \\
1,203-2,204-1\end{array}$ \\
\hline $\begin{array}{l}\text { Food safety management } \\
\text { systems }\left(x_{3}\right)\end{array}$ & $\begin{array}{l}\text { International organizations, investors, } \\
\text { consumers, mass media }\end{array}$ & $S, M, F$ & 2.5 & - \\
\hline $\begin{array}{l}\text { Partnership for sustainable } \\
\text { development }\left(\mathrm{x}_{4}\right)\end{array}$ & $\begin{array}{l}\text { Local communities, partners, educational } \\
\text { and public organizations, state authorities, } \\
\text { suppliers, mass media }\end{array}$ & $S, N, M, F$ & 8.3 & $\begin{array}{l}\text { GRI Standard 203- } \\
\quad 2,204-1\end{array}$ \\
\hline $\begin{array}{l}\text { Environmental efficiency and } \\
\text { social development }\left(x_{5}\right)\end{array}$ & $\begin{array}{l}\text { Public and international organizations, } \\
\text { trade unions, local communities, mass } \\
\text { media }\end{array}$ & $\mathrm{S}, \mathrm{M}, \mathrm{H}$ & $\begin{array}{l}8.4,7.3 \\
15.3\end{array}$ & $\begin{array}{l}\text { GRI Standard } 301 \\
-1-5,303-3,305-2\end{array}$ \\
\hline
\end{tabular}

The Bord's rule refers to a class of expert methods to support economic decision-making regarding the ranking of alternatives.

Ranking is the location of the objects of the study in ascending or descending order of a certain property inherent to them by the experts, which allows one to choose the most significant objects from the investigated set.

According to the Bord's rule, a group of $k$ experts $\left(E=E_{1}, E_{2}, \ldots, E_{k}\right)$ is instructed to organize all variants of the proposed alternatives, which refer to a certain set of $x$ options $\left(\mathrm{x}=\mathrm{x}_{1}, \mathrm{x}_{2}, \ldots, \mathrm{x}_{n}\right)$, where $\mathrm{X}=\left\{\mathrm{X}_{n}\right\}$. The result of organizing the same list of alternatives by each expert is the ranked (prioritized) set of alternatives by the given materiality criterion (ascending or descending) with assigning the number of a natural series (from 1 to $N$ ) to each alternative Equivalence of alternatives is excluded.

The number that each expert assigns to alternative $x \in X$ is interpreted as the rank position of the $r_{X I}$ option $x$ in the ordering of the $k$ expert. The collective rank scale is based on the formula "sum of rank positions":

$$
r_{\Sigma}=\sum_{J=1}^{N} r_{X}^{J}
$$

If the alternatives are ranked in ascending order "from the worst to the best", then the worst version is characterized by 1 , and the best is number $N$.

The results of the ranking of the $5 \mathrm{MHP}$ investigated information requests in 2016 adjusted for sus- tainability context are presented in Table 5 . Team of experts was made by 20 independent experts in the field of agricultural business (business representatives, product consumers, journalists, representatives of educational institutions and public associations). The selection of experts was carried out in accordance with the composition of the main groups of stakeholders of the company, which allows to conclude about the adequacy of the received results of the ranking and the possibilities of using such a technique by the company through the expert's team formation from the stakeholders.

The ordering of the received results and the formation of a collective rank scale allows us to conclude that the ranking of MHP stakeholder information requests is prepared with the following priority:

- $\mathrm{x}_{2}$ - economic efficiency and socio-economic benefits (sum of ranked place - 83);

- $\mathrm{x}_{5}$ - environmental efficiency and social development (65);

- $\mathrm{x}_{3}$ - food safety management systems (61);

- $\mathrm{x}_{1}$ - human capital development (54);

- $\mathrm{x}_{4}$ - partnership for sustainable development (38).

The developed algorithm for prioritization of stakeholder information requests is universal both from the point of view of the investigated sectors, the number of alternative requests, and the number of experts. In addition, it is suitable 
Table 5. Interpretation of ranked and prioritized stakeholder information requests in the food production sector

Source: Developed by the authors on the basis of SAFA/SMART SAFA (2013) and AA 1000 SES AccountAbility (2015).

\begin{tabular}{|c|c|c|c|c|c|}
\hline \multicolumn{2}{|c|}{$\begin{array}{l}\text { Levels of assessment } \\
\text { on the SAFA/SMART scale }\end{array}$} & \multicolumn{2}{|c|}{$\begin{array}{l}\text { Priority (materiality) according } \\
\text { to the standard AA 1000T }\end{array}$} & \multicolumn{2}{|c|}{$\begin{array}{l}\text { Rankings according } \\
\text { to the Bord's rule }\end{array}$} \\
\hline Qualitative assessment & $\%$ of compliance & Class & Description & $\begin{array}{c}\text { Individual } \\
\text { rank }\end{array}$ & $\begin{array}{c}\text { Total score } \\
\text { intervals }\end{array}$ \\
\hline Unacceptable & $0-20$ & $\mathrm{E}$ & $\begin{array}{l}\text { The issue is the minimum } \\
\text { complex of legislative, } \\
\text { institutional and generally } \\
\text { accepted norms }\end{array}$ & 1 & $0-20$ \\
\hline Limited & $21-40$ & $\mathrm{D}$ & $\begin{array}{l}\text { Quite important questions } \\
\text { about which stakeholder will } \\
\text { act in the near future }\end{array}$ & 2 & $21-40$ \\
\hline Average & $41-60$ & $\mathrm{C}$ & $\begin{array}{l}\text { Issues that are universally } \\
\text { recognized and marked } \\
\text { as essential for similar } \\
\text { organizations }\end{array}$ & 3 & $41-60$ \\
\hline Sufficient & $61-80$ & B & $\begin{array}{l}\text { Issues about which are made } \\
\text { strategic statements (an } \\
\text { obligation to key stakeholders) }\end{array}$ & 4 & $61-80$ \\
\hline High & $81-100$ & A & $\begin{array}{l}\text { Direct influence on financial } \\
\text { activity of the company }\end{array}$ & 5 & $81-100$ \\
\hline \multicolumn{6}{|c|}{ Features of the used approach } \\
\hline \multicolumn{2}{|c|}{$\begin{array}{l}\text { Taking into consideration the relevance of } \\
\text { information requests of stakeholders to the } \\
\text { Sustainable Development Goals and to the most } \\
\text { significant challenges for sustainable development } \\
\text { for the food sector }\end{array}$} & \multicolumn{2}{|c|}{$\begin{array}{l}\text { Taking into consideration the } \\
\text { significance of the identified } \\
\text { information requests for responding to } \\
\text { them by the company and inclusiveness } \\
\text { in corporate practice }\end{array}$} & \multicolumn{2}{|c|}{$\begin{array}{l}\text { Taking into consideration expert's } \\
\text { opinions from the number of } \\
\text { internal and external stakeholders } \\
\text { of the company }\end{array}$} \\
\hline
\end{tabular}

for visualization, takes into consideration the best world experience in prioritizing stakeholders' information requests, considering the concept of sustainable development and their significance for stakeholders.

We suggest that interpretation of the results of the ranking of MHP information requests should be carried out not only according to the individual and collective rankings of the experts according to the Bord's rule, but also by the SAFA/SMART scale of the UN FAO, as well as the materiality classes for AA 1000 SES (Table 5).

Among the advantages of the proposed integrated approach to interpreting the results of information requests ranking, there should be:

- simple and unambiguous interpretation of the received ranks;

- compliance with best international experience in evaluating initiatives for sustainable development in the food production sector;

- labeling of stakeholders' information requests according to the criterion of materiality on the basis of the generally accepted standard of interaction with them;

- strengthening the communication with stakeholders and taking into consideration their thoughts;

- possibility of application in each of the studied sectors of the economy.

Interpretation of the obtained results (Table 6) gives the rationale to conclude that the highest priority for consideration in MHP corporate sustainability strategy among its stakeholders information requests has such alternatives as economic efficiency and obtaining additional socio-economic benefits in the regions of the company's presence $\left(x_{2}\right)$.

On the second place are the requests that are related to environmental efficiency and social development $\left(\mathrm{x}_{5}\right)$ and food safety $\left(\mathrm{x}_{3}\right)$. The least important for incorporation into the MHP sustainability are the requests of state authorities and local communities about establishing a partnership in the field of sustainable development. 
Table 6. Interpretation of the ranking of information requests of the MHP in 2016

Source: Own calculation.

\begin{tabular}{|c|c|c|c|c|}
\hline \multirow{2}{*}{ Requests } & \multirow{2}{*}{$\begin{array}{c}\text { Rankings according to } \\
\text { the Bord's rule }\end{array}$} & \multicolumn{2}{|c|}{$\begin{array}{l}\text { Levels of assessment } \\
\text { on the SAFA/SMART scale }\end{array}$} & \multirow{2}{*}{$\begin{array}{c}\begin{array}{c}\text { Priority (materiality) } \\
\text { according to the } \\
\text { standard AA 1000T }\end{array} \\
\text { Class }\end{array}$} \\
\hline & & Qualitative assessment & $\%$ of compliance & \\
\hline- & $0-20$ & Unacceptable & $0-20$ & $\mathrm{E}$ \\
\hline$x_{4}(38)$ & $21-40$ & Limited & $21-40$ & $\mathrm{D}$ \\
\hline$x_{1}(54)$ & $41-60$ & Average & $41-60$ & C \\
\hline$x_{5}(68) x_{3}(61)$ & $61-80$ & Sufficient & $61-80$ & B \\
\hline$x_{2}(83)$ & $81-100$ & High & $81-100$ & A \\
\hline
\end{tabular}

Thus, the high and sufficient level of compliance with sustainability information disclosure was achieved by MHP in terms of financial and op- erational practices, environmental efficiency and social development. Limited disclosure refers to partnership for sustainable development.

\section{CONCLUSION}

Integral information and analytical support for the mechanism of sustainable cross-sector partnership and for tracking progress in achieving the SDG is grounded on prioritizing the most relevant for stakeholders information requests. Practical aspects of proposed research were investigated according to stakeholder information requests specific in real sector of the economy and one of its industries - food production - as a basic industry for ensuring product safety and national progress on SDG 2.

Concept of capitals and multi-stakeholders' approach are the basis for grouping the stakeholders' information requests in different sectors of the economy as providers of various types of capital of the companies: financial, human, natural, social, intellectual, manufacturing. In order to systematize these requests and form an indicative system for sustainability information disclosure about them in companies' non-financial reporting, their classification for real sector of the economy (food production sector) has been developed.

Proposed classification includes the most significant focus issues, dimensions and sustainability criteria, as well as relevant for food companies SDG, targets and Global Reporting Initiative Standards and Guidelines indicators.

Based on the Bord's rule, a procedure for ranking and prioritization of the stakeholders' information requests for the company MHP, operating in Ukrainian food sector, was developed. It allows to identify the most important and material for the company stakeholders' sustainability information disclosure issues in accordance with their industry specificity. According to the results of the procedure, prioritization has been given to the company's stakeholders requests on the scale: SAFA/SMART of the United Nations FAO, the Bord's and the AA 1000 SES.

The advantages of the proposed approach to classification and prioritization of stakeholders' information requests are simple and unambiguous interpretation of the rank for each request; possibility of application in all sectors of the economy; compliance with best international experience in evaluating sustainable development initiatives in a particular industry; strengthening communications with stakeholders on the basis of sustainability reporting. 


\section{ACKNOWLEDGEMENT}

Comments from the Editor and anonymous referees have been gratefully acknowledged. Inna Makarenko gratefully acknowledges financial support from the Ministry of Education and Science of Ukraine "Corporate social and environmental responsibility for sustainable development: stakeholders partnership in the real, financial and public sectors of the economy" (0117U003933).

\section{REFERENCES}

1. AccountAbility (2015). AA1000 Stakeholder Engagement Standard 2015. Retrieved from http:// accountability.org/wp-content/ uploads/2016/10/AA1000SES_2015.pdf

2. Ali, S., Hussain, T., Zhang, G., Nurunnabi, M., \& Li, B. (2018) The implementation of sustainable development goals in "BRICS" countries. Sustainability (Switzerland), 10(7), 2513. https://doi. org/10.3390/su10072513

3. Anzilago, M., Panhoca, L., Bezerra, C. A., Beuren, I. M., \& Kassai, J. R. (2018). Values or hypocrisy: the global reporting initiative mapping in agricultural cooperatives in Paraná, Brazil. Environmental Monitoring and Assessment, 190(8). https://doi.org/10.1007/s10661018-6870-5

4. Astarta (2016). Report on the progress 2016. Astarta-Kyiv. Retrieved from http://www.astartakiev. com/modules/pages/upload/file/ astarta_zvit_web_engl.pdf

5. CSR Case Contest (2018). Цілі сталого розвитку: внесок бізнесу [Tsili staloho rozvytku]. CSR Case Contest Results in 2016-2017. Centre "CSR Development". Retrieved from http://csr-ua.info/ csr-ukraine/article/

6. Czyżewski, A., \& SmędzikAmbroży, K. (2015) Specialization and diversification of agricultural production in the light of sustainable development. Journal of International Studies, 8(2), 63-73. https://doi.org/10.14254/2071 $8330.2015 / 8-2 / 6$

7. Ernst \& Young, GreenBiz Group (2013). Six Growing Trends in Corporate Sustainability. Retrieved from http:// ey.com/Publication/vwLUAssets/
Six_growing_trends_in_corporate_sustainability_2013/\$FILE/ Six_growing_trends_in_corporate_sustainability_2013.pdf

8. Freeman, R. (1984). Edward Strategic Management: A stakeholder approach. Boston. Pitman.

9. Friedman, A., \& Miles, S. (2002). Developing stakeholder theory. Journal of Management Studies, 39(1), 1-21. https://doi. org/10.1111/1467-6486.00280

10. Garvare, R., \& Johansson, P. (2010). Management for sustainability - A stakeholder theory. Total Quality Management \& Business Excellence, 21(7), 737-744. https://doi.org/10.1080/14783363. 2010.483095

11. Gleckman, H. (2016). Multistakeholder governance: $a$ corporate push for a new form of global governance. Retrieved from https://www.tni.org/files/ publication-downloads/state-ofpower-2016-chapter5.pdf

12. Global Reporting Initiative (2013a). G3.1 Guidelines. Retrieved from https://www. globalreporting.org/information/ sector-guidance/sector-guidance/ financial-services/Pages/usngG3.1-Guidelines-with-this-supplement.aspx

13. Global Reporting Initiative (2013b). Sustainability Topics for Sectors: What do stakeholders want to know? Retrieved from http:// www.globalreporting.org/resourcelibrary/sustainability-topics.pdf

14. Global Reporting Initiative (2014). Top 10 GRI Sustainability Aspects for the Agriculture Sector. Retrieved from http:// ga-institute.com/SustainabilityUpdate/2014/09/29/top-10-grisustainability-aspects-for-theagriculture-sector
15. Global Reporting Initiative (2018). GRI Standards. Retrieved https:// www.globalreporting.org/standards/

16. Gonzalez, R. A. (2017). Going back to go forwards? From multistakeholder cooperatives to Open Cooperatives in food and farming. Journal of Rural Studies, 53, 278290. https://doi.org/10.1016/j. jrurstud.2017.02.018

17. Govindan, K. (2018). Sustainable consumption and production in the food supply chain: A conceptual framework. International Journal of Production Economics, 195, 419-431. https://doi. org/10.1016/j.ijpe.2017.03.003

18. Hemmati et. al. (2002). Multistakeholder processes for governance and sustainability: beyond deadlock and conflict in Jan McHarry Paperback. Routledge.

19. International Integrated Reporting Council (2012). Towards Integrated Reporting. Communicating Value in the 21st Century. Retrieved from http://integratedreporting.org/wp-content/ uploads/2011/09/IR-DiscussionPaper-2011_spreads.pdf

20. ISO 26000 - Social responsibility (n.d.). Retrieved from http://www. iso.org/iso-26000-social-responsibility.html

21. Karwat-Woźniak, B. (2009). Highly commercial family farms in the light of the sustainable development of agriculture and rural areas in Poland. Economy \& Sociology, 2(1a). Retrieved from https://www.researchgate.net/ publication/274184242_Highly_commercial_family_farms_in the_light_of_the_sustainable_development_of_agriculture_and_ rural_areas_in_Poland 
22. KPMG (2011). The KPMG Survey of Corporate Responsibility Reporting. Retrieved from http://csr.ee/ wp-content/uploads/2016/03/ KPMHG-International-Survey-ofCSR-2011.pdf

23. Kuribayashi, M., Hayashi, K., \& Akaike, S. (2018). A proposal of a new foresight platform considering of sustainable development goals. European Journal of Futures Research, 6(1) https://doi. org/10.1007/s40309-017-0130-8

24. Masud, M. A. K., Hossain, M. S., \& Kim, J. D. (2018). Is green regulation effective or a failure: Comparative analysis between Bangladesh Bank (BB) green guidelines and global reporting initiative guideline. Sustainability (Switzerland), 10(4). https://doi. org/10.3390/su10041267

25. MHP (2016). MHP non-financial report. Retrieved from http:// www.mhp.com.ua/library/file/gri2016-ukr-final.pdf

26. MHP (2017). CSR Policy of PJSC "Myronivsky Hliboproduct". Retrieved from http://www.mhp. com.ua/library/file/kso-finukr-2017.pdf
27. Monaco, F., et al. (2017). Food Production and Consumption: City Regions between Localism, Agricultural Land Displacement, and Economic Competitiveness. Sustainability, 9(1), 1-20.

28. Podnar, K., \& Jancic, Z. (2009). Towards a Categorization of Stakeholder Groups: An Empirical Verification of a Three-Level Model. Journal of Marketing Communications, 12(4), 297-308. https://doi. org/10.1080/13527260600720376

29. Post, D., \& Preston, L. (2002). Redefining the Corporation: Stakeholder Management and Organizational Wealth. Stanford Business Books.

30. Rockström, J., Williams, J., Daily, G., et al. (2017). Sustainable intensification of agriculture for human prosperity and global sustainability. Ambio, 46(1), 4-17. https://doi.org/10.1007/s13280016-0793-6

31. SAFA (2013). Sustainability Assessment of Food and Agriculture systems guidelines. Version 3.0. FAO.

32. SDD Database (2018). Sustainability disclosure database. Retrieved from http://database.globalreporting.org/search/

33. SDG (2017). Sustainable Development Goals in Ukraine. Retrieved from http://www.un.org.ua/en/ millennium-development-goals

34. Sen, S. K., Ongsakul, V. (2018). Clusters of sustainable development goals: A metric for grassroots implementation. Sustainability (United States), 11(3), 118-126. https://doi. org/10.1089/sus.2018.0007

35. Tarquinio, L., Raucci, D., \& Benedetti, R. (2018). An investigation of Global Reporting Initiative performance indicators in corporate Sustainability Reports: Greek, Italian and Spanish evidence. Sustainability (Switzerland), 10(4). https:// doi.org/10.3390/su10040897

36. UNCTAD (2016). Enhancing the role of reporting in attaining the Sustainable Development Goals: Integration of environmental, social and governance information into company reporting: Note by the UNCTAD secretariat. Geneva, October 4-6, 2016.

37. Wheeler, D., \& Sillanpa, M. (1997). The stakeholder corporation: A blueprint for maximizing stakeholder value. London: Pitman. 